Issues in theory and methods of teaching foreign languages.

Проблеми теорії і методики навчання іноземних мов

УДК 811.111

https://doi.org/10.31548/philolog2021.01.137

\title{
THEMATIC ANALYSIS OF ENGLISH COURSE FOR THE LAND MANAGEMENT FACULTY FRESHMEN
}

\author{
K. H. YAKUSHKO, PhD in Pedagogy, Senior lecturer, \\ National University of Life and Environmental Sciences of Ukraine \\ E-mail: vukladach@ukr.net \\ https://orcid.org/0000-0001-6977-8441
}

\begin{abstract}
Abstact. The modern demand to organize studying is concluding some syllabuses to learn different disciplines in general and foreign language for professional purposes in particular. At the same time the attention amplifies to the research of syllabuses basic structural content. The purpose of article is to determine topical content structure of the foreign language course for specialty "Geodesy and Land planning" initial bachelor's degree program's studying stage and performing adequate comparative characteristics of topical content within the first and the second semesters on the basis of pedagogical observation during 2019/2020 curriculum. The result of investigation lays in 5 conclusions. The perspectives of investigation is the analysis of the freshmen's mistakes types while working with electronic course "English for Geodesy and Land Planning", analysis of the activity of fulfillment, the correctness of content design and understanding of the set tasks either aiming to represent general and personal recommendations to improve gaps in freshmen's foreign language knowledge, abilities and skills or further correction of topical content of studying course being based on the real students' demands.
\end{abstract}

Key words: comparison, thematic semester content, syllabus of the discipline "Foreign language", freshman, bachelor, specialty "Geodesy and land planning".

Introduction. Nowadays it is important to follow some modern demands to organize studying through concluding some syllabuses to learn different disciplines in general and foreign language for professional purposes in particular. At the same time the attention amplifies to the research of syllabuses basic structural content as well as performance of similar courses content analysis.

Recent researches and publications. Our recent researches and publication aiming to involve into textual content of electronic studying course for the future land managers [5] being based on the curriculum to study English by different directions students in the aspect of applying psycholinguistic images [6] through developing students' foreign language professional communicative skills in general [4]. The example of the textual content to conclude our own abovenamed textual educational planning as a material to be analyzed belonged to recommendations by I. V. Grabovska in the aspect to develop metacommunicative contactestablishing topicalizing questions in modern English dialogic thematic filling [2], adequate general guidelines [3] and the concrete recommendations by $\mathrm{O}$. Botvinko-Botiuk who earlier elaborated syllabus for studying discipline "Foreign language for professional communication(English)" for students according to the educational program"Land planning and cadastre", specialty 193 "Geodesy and Land Planning" [1].
The purpose of an article is to determine topical content structure of the foreign language course for specialty "Geodesy and Land Planning" initial bachelor's degree program's studying stage and performing adequate comparative characteristics of topical content within the first and the second semesters on the basis of pedagogical observation during 2019/2020 curriculum.

Data and methods. To meet our objectives the method of information analysis, the synthesis method, the comparative method, the method of linguistic description, semantic and syntactic methods, interpretation method, the mixed methods of quantitative and qualitative analyses were used. The background included papers concerning studying methodological complex and adequate electronic course being authorized either by the chairman of the English Department for Technical and Agrobiological Specialties or by the dean of the Faculty of Land Management within the National University of Life and Environmental Sciences of Ukraine in 2019 and 2020.

Results. The first stage of research was to distinguish main types of the studying results to be achieved while two semesters studying in general:

1) A: to know the title of the university, faculty and specialty, to use knowledge of the rules of reading and transliteration in practice as well as collective body of group and general table of land management terms, to be able to 
introduce own personality and native region, the titles of geometric figures and arithmetic operations;

2) B: to know some basic requirements for the presentation, to be able to develop and to represent adequate presentation for describing the characteristics of every student's native region, the prospects of land surveyor's work and the studying at the faculty of Land management within the National University of Life and Environmental Sciences of Ukraine;

3) C: to know the lexical and grammar features of concrete topical specialized text; to perform consolidating exercises and creative tasks, to be able to conclude appropriate own conversational situations and dialoguesdiscussion of features of studying of concrete topic in general;

4) D: to be able to work with Moodle system within concrete Module, to perform automatic testing, analyze errors to make subsequent attempts;

5) $\mathrm{E}$ : to be able to present the results of independent work in the form oral interview concerning concrete Module topics;

6) $F$ : to be able to react and to comment and to improve errors in pronunciation, writing and concluding own English sentences from memory without additional supporting materials;

7) G: to know the main questions and answers about the content of the semester, know the structure of the exam answer, to know the stages of the exam attestation, to be able to apply the knowledge in practice through a testing and to archive the results in the appropriate folder;

8) $\mathrm{H}$ : to know main scientific problems of the land management branch, the scheme and examples for annotating, to write own theses and summary according to adequate topical direction;

9) I: to know main conversational clichés, to be ready to communicate, and to express conversational intentions, to ask and answer basic questions to be combined as professional and common speech.

The second stage for the further analysis was to distinguish 10 types of tasks on the English periods: 1) Type 1 task: general introductional discussion; 2) Type 2 task: reading, writing and discussing a synopsis (shorten necessary theoretical notes) and vocabulary; 3 ) Type 3 task: writing essay, working with audio, Internet sources and video to express own opinion; 4)Type 4 task: participation in topical discussion and adequate game; 5) Type 5 task: preparing, e-learn sending and oral defense of topical practical work; 6) Type 6 task: preparing, e-learn sending and oral defense of topical individual task or presentation; 7) Type 7 task: Moodle elearn testing; 8) Type 8 task: task folder archiving and attestation instruction; 9) Type 9 task: the work with scientific articles, Internet sources, annotating, theses writing; 10) Type 10 task: writing and representing scenario with participants' replica and props indication to solve some problematic situation concerning land manager's real life concluding crosswords and interviewing.

The third stage of analysis is the involving of the previous shortened symbols of studying results and lessons tasks according to the concrete themes.

During the first semester of studying the future land managers studied Theme 1 "Land Management Introduction" with A, B, C studying results involving Type 1 task, Type 2 task, Type 3 task, Type 4 task and Theme 2 "Land Law" with studying result $C$ as well as Type 2 task, Type 3 task, Type 4 task, Type 5 task and Type 6 task. Theme 3 "E-learn Module1 Test Representing Results of the Module 1 Individual Tasks" being concerned with D, E, F studying results, Type 3 task and Type 7 task. Besides, Theme 4 "Land Cadastre. Soils" dealt with studying $\mathrm{C}$ result and Type2 task, Type 3 task, Type 4 task, Type 5 task, Type 6 task and Theme 5 "Geodesy and Geodetic Instruments" included C result as well as Type 2 task, Type 3 task, Type 4 task, Type 5 task and Type 6 task. The last Theme 6 "E-learn Module2 Test Representing Results of the Module 2 Individual Tasks" was connected with D, E, F studying results and Type 3 task, Type 7 task and Type 8 task alike to the Theme 7 "Preparation to Credit Passing" with G studying result.

It was also distinguished that the topics concerning the second semester included Theme 8"Cartography" dealt with Result C and such tasks as Type 2 task, Type 3 task, Type 4 task, Type 5 task and Type 6 task dissimilar to Theme 9 "GIS. GPS" with C result and Type 2 task, Type 3 task, Type 4 task, Type 5 task, Type 6 task. Besides, thematic structure of the second semester dealt with Theme 10 "E-learn Module3 test Representing Results of the Module 3 works applying D, E, F results and Type 3 task, Type 7 task as well as Theme 11 "Annotation" included $\mathrm{H}$ result and Type 9 task. The specific feature of the second semester was the shorter list of themes but including more number of hours for studying Theme 12 "Conversation" with I result and Type 10 task comparing to Theme 13 "E-learn Module 4 Test representing Results of the Module 4 works" with its D, E, F results or Type 3 task and Type 7 task. The last theme 14 "Preparation to Exam" included Type 7 task and Type 8 task with the $G$ result.

Discussion. The above named analysis deals either with the general demands to conclude the thematic structure of foreign language courses by I. Grabovska, L. Berezova foreign language course topics for freshmen in land management and types of activities by 
K.Yakushko by O. Botvinko-Botiuk being fixed in adequate electronic courses. The result of investigation lays in 5 conclusions: 1 ) the first year bachelor's degree program to study foreign language either on the first or the second semesters is aimed to gain main categories, grammar backgrounds, basic vocabulary and models of word combinations to form dialogical and monologue skills for another language communication, skills and abilities of selforganization of work with foreign textual material, Moodle system operation, the backgrounds of concluding crosswords and presentations, the work with thematic foreign audio and video material, land manager's problematic real life discussion during introducing certified electronic studying course "English for Geodesy and Land Planning" because of fulfillment, discussion, preparation and defense of practical works and individual tasks of the adequate electronic course; 2) the first semester of the first year program to study English with the planned time-table as one or two periods in a week deals with the adaptive process of familiarization of general principles of work with the electronic course (sending works, testing, searching of the necessary material, schedule of works performance, etc.), familiarization with collective body of group and general table of land management terms, introducing own features and native region, familiarization with features to study at the Faculty of Land management within the National Universities of Life and Environmental Sciences of Ukraine and different trends of land manager's activity in the sphere of geodesy and land planning, taking into account the importance of

\section{References}

1.Botvinko-Botiuk, O. M. (2020). Sylabus navchalnoi dystsypliny "Inozemna mova profesijnoho spilkyvannia (anglijska)" dlia zdobuvachiv vushchoi osvity, yaki navchajutsia za osvitno- profesijnoju programoju"Zemleustij ta kadastr", spetsialnist 193"Geodezia ta zemleustrij" [Syllabus of the studying discipline" Foreign language for professional communication (English)" for students according to the educational program" Land planning and cadastre", specialty 193"Geodesy and Land Planning].URL: http://ep3.nuwm.edu.ua/18847 [in Ukrainian].

2. Grabovska, I. V. (2019). Metacommunicative contact-establishing topicalizing questions in modern English dialogic discourse. International journal of philology. 10 (1), 38-41 10(1) DOI: http://dx.doi.org/10. 31548/philolog2019.01.038

3. TNPU. (2020). Metodychni rekomendatsii do ukladannia sylabusiv [The guidelines to mathematical measurements for the work of the land surveyor as well the role of land law, cadastre and soil studying in modern science;3) in the second semester of the program to study English by freshmen less attention is paid on the adaptation stage, the projection is accentuated on the special features of cartography, geodesy, use of geodetic devices, satellite navigation, GIS; 4) either the first or the second semesters deal with the 5 predicted results of studying and 8 types of basic tasks on lessons to be added by some additional ones in the second semester; 5) in the second semester because of the addition of the number of hours up to the two periods every week it is developed additional opportunity to repeat and work out new lexical material on the basis of the known communicative clichés and grammar basic rules, familiarization with the backgrounds of scientific articles annotating, basic questions to keep the different topics conversation going, the phrases to express main communicative intentions, the abilities for developing scripting skills and using learned clichés to disseminate basic real-life dialogues. The perspectives of investigation is the analysis of the freshmen's mistakes types while working with electronic course "English for Geodesy and Land Planning", analysis of the activity of fulfillment, the correctness of content design and understanding of the set tasks either aiming to represent general and personal recommendations to improve gaps in freshmen's foreign language knowledge, abilities and skills or further correction of topical content of studying course being based on the real students' demands.

conclude syllables] URL http:/tnpu.edu.ua/ about/public_inform/upload/2020/metodychni_rek omendatsiji_sylabus.pdf [in Ukrainian].

4. Yakushko, K. H. (2020). The categories of specialized vocabulary in the sphere of automation to develop students' foreign language communicative skills. Modern researches in philological sciences: collective monograph: Romania: North University Centre of Baia Mare, 427-448. DOI: https://doi.org/10.30525/978-9934$588-37-2 / 25$

5. Yakushko, K.H. (2020). Kurs: Anglijska mova GiZ [English course for Geodesy and Land planning]. URL: https://elearn.nubip.edu.ua/ course/view.php?id=2316

6. Yakushko, K. H., Berezova, L. V. (2020). The search of psycholinguistic images for the technical terms on the professionally oriented English lessons. International journal of philology, Vol. 11, № 2, 135-139. DOI: http:// doi.org/10.31548/philology 2020.02.135. 
Issues in theory and methods of teaching foreign languages.

Проблеми теорії і методики навчання іноземних мов

\title{
ТЕМАТИЧНИЙ АНАЛІЗ КУРСУ АНГЛІЙСЬКОЇ МОВИ ДЛЯ ПЕРШОКУРСНИКІВ ФАКУЛЬТЕТУ ЗЕМЛЕВПОРЯДКУВАННЯ
}

\author{
К. Г. Якушко
}

\begin{abstract}
Анотація. Актуальність дослідження - у описі практичного досвіду виконання сучасних вимог організації навчання щодо оновлення тематичних планів різних дисциплін у цілому та іноземної мови за профресійним спрямуванням зокрема. Метою статті $\epsilon$ опис тематичного наповнення структури курсу іноземної мови для спеціальності «Геодезія та землеустрій» на початковій стадії навчання на бакалавраті та здійснення відповідної порівняльної характеристики тематичного наповнення у першому та другому семестрах на основі педагогічного спостереження 2019/2020 р. Результатом дослідження є 5 висновків: 1) програма першого курсу вивчення іноземної мови на бакалавраті і у першому, і у другому семестрах спрямована на оволодіння основними категоріями, граматичного ряду, базовою лексикою та основними моделями словотворення, на формування діалогічних і монологічних навичок іншомовного спілкування, вмінь та навичок самостійної роботи з іншомовним текстом, системою Moodle, засвоєння основ укладання кросвордів, презентацій, роботи з тематичним іншомовним аудіо-відеоматеріалом, обговорення проблемних ситуацій стосовно реального життя землевпорядника під час ознайомлення та закріплення теоретичного матеріалу атестованого ЕНК «Англійська мова: ГІЗ» через виконання, обговорення та практичних робіт й індивідуальних завдань відповідного електронного курсу; 2) у першому семестрі з меншою (у порівнянні з другим семестром) кількістю годин на вивчення англійської мови першокурсниками фракультету землевпорядкування акцентується увага на адаптаційному процесі ознайомлення з загальними принципами роботи 3 електронним курсом (надсилання робіт, виконання тестів, пошуку потрібного матеріалу, графріку представлення робіт, фуннкцій обміну повідомленнями та іншими ресурсами), знайомство $з$ одногрупниками та викладачем, таблицею термінів землевпорядкування у цілому, представлення себе та особливостей рідного краю, ознайомлення з особливостями навчання на фракультеті землевпорядкування Національного університету та природокористування України та огляд напрямів діяльності фахівия з спеціальності "Геодезія і землеустрій», прийняття до уваги значення математичних вимірювань для роботи землевпорядника, ролі земельного права, кадастру та грунтознавства на теренах сучасної науки; 3) у другому семестрі програми вивчення англійської мови на першому курсі вже менше надана увага адаптаційному етапу, зміщена проекція на ознайомлення з основами картографрії, геодезії, використання геодезичних приладів, супутникової навігації, ГІС; 4) силабус і першого, і другого семестру грунтується на охопленні 5 передбачених результатів навчання та 8 типів основних завдань з розширенням означеного переліку результатів та типів завдань у другому семестрі; 5) у другому семестрі завдяки збільшенню обсягу годин на вивчення іноземної мови з'являється можливість повторення та відпрацювання нового лексичного матеріалу на основі засвоєних1 раніше комунікативних кліше та граматичних основ, ознайомлення з основами анотування наукових статей, базовими питаннями для підтримання розмови на різні теми, висловами для виявлення основних комунікативних намірів, розвитку умінь складання сценаріїв та вживання засвоєних кліше для поширення базових діалогів, дотичних до реального життя. Перспективами дослідження $\epsilon$ аналіз типів помилок першокурсників при роботі з електронним курсом «Англійська мова: Гіз», аналіз активності виконання, правильності оформлення та розуміння поставлених завдань з метою як надання загальних та персональних рекомендацій з усунення прогалин у іншомовних знаннях, уміннях та навичках першокурсників, так і подальшого коригування розробником курсу його змістового наповнення, виходячи з реальних потреб студентів.
\end{abstract}

Ключові слова: порівняння, тематичне посеместрове наповнення, силабус дисципліни «Іноземна мова», першокурсник, бакалаврат, спеціальність «Геодезія та землеустрій». 